\title{
Dostoevsky in English and Shakespearean Universality: A Cautionary Tale
}

\begin{abstract}
This is the second of a pair of articles addressing the relationship between Dostoevsky's novella Notes from the Underground and Shakespeare's Hamlet. The first article considered the similarities between the two texts, using David Magarshack's 1968 English translation of the Notes, before discussing the wider phenomenon of Hamletism in nineteenth-century Russia. In this article, the author focuses on the problem of translation, identifying a handful of instances in the Magarshack translation that directly 'insert' Shakespeare, and Hamlet in particular, into Dostoevsky's text. It is argued that these allusions or citations overdetermine the English reader's experience of Shakespeare-and-Dostoevsky, or Shakespeare-in-Dostoevsky. Returning to the question of Shakespeare's status in Europe in the nineteenth century, the article concludes with a critique of Shakespearean 'universality' as it manifests through the nuances of translation.
\end{abstract}

Keywords: Shakespeare, Dostoevsky, Russia, Underground, Hamlet, translation, universality.

\section{Afterlives in Translation}

In a previous article ("Hamlet Underground: Revisiting Shakespeare and Dostoevsky", Thurman 2018), I explored the ways in which Shakespeare's Hamlet may be seen to hover-like Hamlet's father's ghost—over Dostoevsky's Notes from the Underground: that is, over the self-contained world of the text and over its narrator, as well as over the historical context in which it was written, over its author and over his contemporaries. Yet twenty-first century readers of both Shakespeare and Dostoevsky must also acknowledge that, to some extent at least, our experience of the former text (c.1600) is now also affected by the latter (1864). There is something of Derrida's supplementarity in this; alternatively, although we may be reluctant to invoke Harold Bloom and The Anxiety of Influence, it is not inappropriate to suggest that Dostoevsky 'kills

* University of Witwatersrand (Johannesburg, South Africa). 
off' his strong precursor, Shakespeare, by reformulating the Prince of Denmark into the irredeemable narrator-protagonist of his novella. If Dostoevsky was closer to this figure in more ways than he realised, or could admit, might this equally apply to the Underground Man's rejection of the banal claim that "Shakespeare is immortal"? (Dostoevsky/Magarshack 165)

Shakespeare's "immortal" plays are passed down not as autonomous works but as read, performed, interpreted and appropriated texts. They are always-already mediated when we encounter them. Both Shakespeare and his Hamlet, then, experience a kind of death-in-life: the author, through the appropriation and adaptation of his works; the character, through an 'afterlife' over which he has no control. "Report me and my cause aright," Hamlet enjoins Horatio - the Danish Prince is acutely aware of his legacy, of "what a wounded name/...shall live behind [him]" (Hamlet 5.2.339-45) if the story of his life and death is distorted. Hamlet cannot, however, control what history will make of him. His image can quite easily be twisted into, for instance, that of the loquacious, peevish, malicious, deluded Underground Man. Hamlet dies declaring, "The rest is silence" (5.2.358). But death does not necessarily result in silence, as the presence of Hamlet's father's ghost demonstrates. It is ultimately the motif of the ghost - of the father figure, of generations gone by, of spectral precursors - that defines Hamlet's afterlife. Shakespeare (as both author and 'authority'), Hamlet and Hamlet each call writers like Dostoevsky to follow them, as it were, up to the parapets of Elsinore. And sometimes it seems as if texts like Notes from the Underground, along with the characters within those texts, have themselves heeded such a call.

The complexities of these relationships are compounded by the creative act of interpretation that is translation. Hamlet and the Underground Man are both obsessed with "words, words, words" (2.2.189) - a repetition that is echoed in the Notes as "lies, lies, lies" (128) - because the ambiguity and often the opacity of language obscures their understanding of the world and others' understanding of them. Translation presents an opportunity to clarify, or simplify, but it also increases the risk of misrepresentation or miscommunication. In the previous article, I gave an account of my own first encounter with Dostoevsky's novella in David Magarshack's English translation: as a graduate student who had limited experience with studying texts in translation, I paid scant attention to the linguistic distance that Shakespeare's words had to travel for me to recognise them in the pages of a translation of Dostoevsky's text. My present undertaking provides an opportunity to reconsider this blind spot, or to render 'visible' those typically 'invisible' translating choices that can frame a reader's interpretation of a given text.

Dostoevsky was not familiar with Hamlet in its early modern English original (or originals, if we keep in mind the quarto and folio variants of the play). The majority of his readers were probably best acquainted with Nikolai 
Polevoy's landmark 1837 translation, which was fairly free in its use of 'modernised' Russian. So, what happens when Dostoevsky is translated into English - when what may appear to be Shakespearean resonances in Dostoevsky get translated from Russian 'back' into a language that itself has changed substantially since the early modern period? Those resonances may be sublimated, hidden or even erased. Alternatively, the presence of Hamlet (and Shakespeare himself, like Hamlet's father's Ghost) can be foregrounded; this is in fact what results from Magarshack's decision to use phrases borrowed from Shakespeare in his translation of Notes from the Underground.

The Magarshack text was first published in 1968. Sporadically over the course of two decades following the Second World War, Anglophone critics had drawn connections between Hamlet and the Underground Man-from John Cowper Powys' casual association of the two figures in a throwaway remark in his 1946 book on Dostoevsky (I shall return to Powys later in this article) to Stanley Cooperman's sustained comparison in a 1968 essay. Throughout this period, the dominant English translation of the Notes remained that of Constance Garnett-a version since dismissed out of hand by the likes of Kornei Chukovsky:

In reading the original, who does not feel the convulsions, the nervous trembling of Dostoevsky's style? It is expressed in convulsions of syntax, in a frenzied and somehow piercing diction where malicious irony is mixed with sorrow and despair. But with Constance Garnett it becomes a safe blandscript: not a volcano, but a smooth lawn mowed in the English manner-which is to say a complete distortion of the original. (Chukovsky 220-21)

Magarshack's translation of the Notes was thus a welcome departure; David Remnick is wrong, writing about the Russian "translation wars", to dismiss him as "one of Garnett's epigones" (n.p.). But in departing from Garnett's VictorianEdwardian style - in 'modernising' the text-Magarshack also, paradoxically, had recourse to early modern English: that is, to Shakespeare's English. There are five instances of Magarshack inserting into his translation of Notes from the Underground phrases that function as allusions to, or direct citations of, passages in Shakespeare's plays. Chief among these is Hamlet.

The numbered extracts below are also listed in Appendix A / Table 1 along with the equivalent passages in Garnett's translation and the earlier version of C.J. Hogarth (1913), as well as two more recent translations by Pevear and Volokhonsky (1993) and Natasha Randall (2012). In none of the passages from the other translations are there any Shakespearean traces. Here it must be emphasised that a close reading of these passages in the original Russian, paired with the text of Polevoy's Gamlet - the Russian translation of Hamlet with which Dostoevsky was most familiar-confirms that there was no 
explicit attempt on Dostoevsky's part to quote Shakespeare's play directly. ${ }^{1}$ The Shakespearean echoes are thus Magarshack's invention.

\section{1. "Yes, gentlemen, it is only among us that the most arrant knave can be perfectly and even sublimely honest at heart..."}

(Dostoevsky/Magarshack 135)

Other translators have rendered the delightful Russian insult ПОДЛЕ́Ц [podlets] as "rascal", "rogue" or "scoundrel"; "scumbag" might be the closest colloquial term. Magarshack's choice, "arrant knave", has a decidedly early modern and Shakespearean ring. While Shakespeare uses variations on the phrase "arrant knave" in 2 Henry IV, Henry $V$ and Much Ado About Nothing - it would likely have been fairly common in his time-it has particular overtones connected to two well-known pronouncements in Hamlet.

Hamlet: There's ne'er a villain dwelling in all Denmark But he's an arrant knave.

(Hamlet 1.5.126-7)

Hamlet: Get thee to a nunnery. Why wouldst thou be a breeder of sinners? I am myself indifferent honest, but yet I could accuse me of such things that it were better my mother had not borne me. I am very proud, revengeful, ambitious, with more offences at my beck than I have thoughts to put them in, imagination to give them shape, or time to act them in. What should such fellows as I do crawling between earth and heaven? We are arrant knaves, all. Believe none of us. Go thy ways to a nunnery. Where's your father?

(Hamlet, 3.1.128-132)

"Arrant knaves" expresses Hamlet's simultaneous disgust at Claudius, his selfdisgust and his disgust with all his fellow-men-which may be applied quite easily to the Underground Man. The context of the second use of the phrase is also significant in terms of the Notes: this is part of Hamlet's misogynistic rant at Ophelia, and when he instructs her to go to a "nunnery" (slang for a brothel) he is endorsing the angel/whore binary that also lies behind the Underground Man's treatment of the prostitute Liza, which is in turn a function of his selfloathing.

1 I am indebted to Dmitry Shkatov for his analysis of Polevoy's Gamlet and Dostoevsky's Zapiski iz Podpol'ya. 


\section{2. "... I bore no resemblance to the gentleman who in his pigeon-livered confusion had sewed a piece of German beaver to the collar of his overcoat."}

(Dostoevsky/Magarshack 143)

Here we may recall that the narrator of the Notes tells us at the outset that there is something wrong with his liver. Yet the direct translation of Dostoevsky's куринного сердца [kurinnogo serdtsa] is "chicken-hearted" (variations on this are chosen in all the other English texts cited in the Appendix). With Magarshack's "pigeon-livered" we are very firmly in Denmark; the first recorded use of the adjective is in Hamlet.

Hamlet:
Who calls me 'villain"? Breaks my pate across?
Plucks off my beard and blows it in my face?
Tweaks me by the nose? Gives me the lie i'th'throat
As deep as to the lungs? Who does me this?
Ha!
'Swounds, I should take it, for it cannot be
But I am pigeon-livered and lack gall
To make oppression bitter, or ere this
I should have fatted all the region kites
With this slave's offal. Bloody, bawdy villain!
Remorseless, treacherous, lecherous, kindless villain!
O vengeance!

(Hamlet 2.2.530-44)

This is a Hamlet / Underground Man who is aware of an audience-who plays up to that audience even as he berates himself - and who, conscious of being judged by others, works himself into a state of righteous vengeful anger.

\section{3. "He would even risk his cakes and ale and deliberately set his heart on the most deadly trash..."}

(Dostoevsky/Magarshack 120)

"Cakes and ale", one might argue, is purely idiomatic; surely, we are not expected to find some equivalence between the Notes and Twelfth Night?

Sir Toby Belch: (To Malvolio) ... Dost thou think, because thou art virtuous, there shall be no more cakes and ale?

(Twelfth Night 2.3.108) 
Well, perhaps there is a thematic resonance between Malvolio's pious disdain for the hedonism of Sir Toby Belch and company and the Underground Man's bitterness towards the drunken jollity of the farewell party for his nemesis Zverkov (although he, too, gets very drunk; and he, too, goes to the brothel). But let's assume that Magarshack, while conscious of this as a specifically Shakespearean phrase, is not using it with any deliberate intertextual significance. Even then, its idiomatic use reinscribes the debt of the English language to Shakespeare, and therefore the debt of all English-speakers, native or otherwise, to Shakespeare. In other words, we might say, it entrenches the notion of Shakespearean universality - a subject to which I shall return.

\section{4. "Quite right, but there's the rub! I'm sorry, gentlemen, to have gone on philosophising like this..."}

(Dostoevsky/Magarshack 118)

"There's the rub" is arguably also idiomatic. But consider the context in Hamlet:

Hamlet: To be or not to be - that is the question

To die, to sleep -

To sleep, perchance to dream. Aye, there's the rub,

For in that sleep of death what dreams may come,

When we have shuffled off this mortal coil,

Must give us pause ...

(Hamlet 3.1.57-69)

This is Hamlet's most famous speech, and certain phrases from it-including "there's the rub" - are attached to Hamlet even by those who haven't watched or read the play. Here the allusion serves to entrench the connection between two over-thinking, paralysed, 'cowardly' characters: Hamlet and the Underground Man.

\section{5. “... I'm every bit as wretched as you are and wallow in filth on purpose - because I, too, am sick at heart."}

"Sick at heart" is not specific to Hamlet (it is in Macbeth too), nor is it exclusively 'Shakespearean'. Moreover, while Hamlet refers to "how ill all's here about my heart" (5.2.197), it is Francisco who speaks the actual line in the opening scene. But as an early modern coinage - its use was first recorded in 1581 - the phrase is still strongly associated by latter-day readers with Shakespeare. 
Francisco: For this relief, much thanks; 'tis bitter cold And I am sick at heart.

(Hamlet 1.1.8)

Macbeth: $\quad$... Seyton! - I am sick at heart, When I behold - Seyton, I say! - This push Will cheer me ever, or disseat me now. I have lived long enough. My way of life Is fall'n into the sere, the yellow leaf, And that which should accompany old age, As honor, love, obedience, troops of friends, I must not look to have ...

(Macbeth 5.3.16-30)

For readers of the Notes who know their Shakespeare, Macbeth calling for Seyton to bring his armour may also match the Underground Man: desperate, raging, somewhat incoherent, full of regret, isolated, but defiant to the last.

\section{"The Fellow in the Cellarage" and "Stellified Shakespeare"}

These quotations are, separately and collectively, effective in characterising the Underground Man. The Shakespearean allusions thus enrich a particular reading of the Notes - that is, a reading based on Hamlet. But they also introduce a potential pitfall. The problem with presenting the Underground Man as a Hamlet-figure in this way is that it can become the sole lens through which English readers familiar with Shakespeare's plays interpret Notes from the Underground. We may no longer be attuned to other literary and philosophical influences; indeed, worse, we may no longer be able to read Dostoevsky without hunting for such influences. A single-minded focus on Hamlet as antecedent of the Underground Man can also lead to overblown claims, clumsy literary criticism or - a particular risk for Shakespeare scholars - an emphasis on textual fragments removed from their dramatic or theatrical context.

Consider Yasuhiro Ogawa's proposal that "Hamlet's correlative to the Dostoevskian 'underground' is the 'nutshell in [which] I could be bounded, and count myself a king of infinite space-were it not that I have bad dreams'." (Ogawa 208n) Ogawa's interest is in the grotesque, and he suggests that “another name for both Hamlet's 'nutshell' and Dostoevsky's 'underground' is the 'grotto' in our diction: their claustrophile, reclusive way of living is 'grottoesque', that is, grotesque." The comparison is intriguing, but framed in this way it is somewhat contrived and inappropriate. While both the "nutshell" and the "funk-hole" are private spaces, offering a retreat and protection from the world and its responsibilities, Hamlet uses the image to set the public "prison" of 
Denmark in opposition to his internal life; for the Underground Man, by contrast, both the public and the domestic spheres are claustrophobic. Whereas the content of Hamlet's dreams has been the subject of much conjecture, the narrator of the Notes gives a fairly detailed account of the moods and events in his dreams - which are themselves not generic, for they veer from the idealistic and romantic to the nightmarish and grotesque.

In a similar instance of misdirected comparison John Cowper Powys fuses the two Hamlets, father and son, when he ropes together the Underground Man and "the ghost in Hamlet, 'the fellow i'the cellarage"" (Powys 82). This rather literal equivalence (they are both 'below the floor'), it is implied, is accompanied by a depressed spiritual and emotional state that may nonetheless be elevated: "a human soul ... who has it in him, or 'in his stars,' to rise to the sublimest height of redemption." Yet Powys ignores the performance context, and the fact that Hamlet's line cajoling Horatio and Marcellus to swear to secrecy ("Come on, you hear this fellow in the cellarage. Consent to swear..." 1.5.151) is clearly an in-joke, a chance for the actor playing Hamlet to break the fourth wall and to mock the device of the Ghost's 'voice' emerging from under the stage. Stanley Cooperman, by contrast, is aware of this dynamic and, in his more sustained comparison between play and novella, emphasises the metatheatrical element; Konstantin Mochulsky, likewise, affirms the similarities between Hamlet and the Underground Man as self-conscious performers. ${ }^{2}$ Powys' quotation of the phrase "in his stars" is also vague: as a generic intimation of fate, it could come from Romeo and Juliet or King Lear, but Powys is probably thinking of Julius Caesar - in which case it is a misquotation, for Cassius is actually trying to persuade Brutus against fatalism: "The fault ... is not in our stars/But in ourselves, that we are underlings" (Julius Caesar 1.2.141-42). This 'generic' Shakespeare, in which different plays and performance contexts are essentially fungible, is, I want to propose, one consequence of too readily celebrating Shakespeare's universality.

Powys' stellar misappropriation - "in his stars"-is serendipitous for my purposes here. In my previous article on "Hamlet Underground", I concluded the analysis with a discussion of 'Hamletism' - one of the more prominent manifestations of Shakespeare's apotheosis in the nineteenth century, both in Russia and in western Europe. Yet the discourse of Shakespearean universality that developed during this period is, as Todd Borlik has shown, inextricable from competition between European nations over imperial territories. Borlik provides a fascinating account of what he calls "the stellification of Shakespeare" (6) by investigating the nomenclature of Uranus and its moons,

\footnotetext{
2 "The underground existence becomes fantasy; this is a game in front of a mirror. The man suffers, rejoices, is angry ... with complete sincerity. But each sensation is reflected in the mirror of consciousness; in the actor there sits a spectator who appreciates his art." (Mochulsky 248)
} 
from the planet's discovery by William Herschel in 1781 to the naming of its moons after Shakespearean characters by Herschel's son John in 1852 (a practice that has since been extended to 25 Uranian satellites). Conflict in the eighteenth century over the naming of celestial bodies-particularly between French and British astronomers-was, Borlik affirms, a continuation of "AngloFrench rivalry in empire-building". In the nineteenth century, while this imperial competition intensified not only between Britain and France but between various European powers, Shakespeare's elevation to a "pan-European sensation" (with even the French eventually capitulating) made possible Herschel junior's patriotic gesture: "Continental astronomers would not allow England to extend its empire out to the stars. In consolation, John Herschel devised an ingenious sleight of hand: name the Uranian satellites after the English national poet par excellence." (Borlik 5)

This historical quirk presents us with a novel way of approaching the universalist discourse: the story of Shakespeare's stellification "reflects and confirms" his status in the nineteenth century as a "cosmopolitan" literary figure perceived as "transcend[ing] cultural-political boundaries" (Borlik 3), even as "English pride in Shakespeare as 'the national poet' remained undimmed. Naming the Uranian moons after his characters thus managed to conflate universality and Englishness." (7) Such a conflation was beneficial to John Herschel when he arrived in South Africa to establish an astronomical observatory in Cape Town as part of "the race between the European imperial powers to chart and label the cosmos in their own image" (9). And, Borlik argues, given that Herschel became involved in the development of the South African schooling system ("Herschel's views align with those of other colonial educators who advocated the study of Shakespeare for moral, utilitarian and nationalistic motives"), the fusion of his astronomical work and his Shakespearean interests "cannot be easily divorced from the 'civilising mission' of imperialism" (10). ${ }^{3}$

I provide this synopsis of Borlik's article to give readers some idea of why, as a South African scholar, I cannot engage with Dostoevsky, Shakespeare, the Underground Man, nineteenth-century Hamletism and twentieth-century translation without keeping in mind my own country's history. This demands an awareness of the ways in which Shakespeare's 'universality' has been created and is sustained, for the politics of Shakespeare studies in South Africa are inevitably linked to debates about 'universality' and 'particularity'. ${ }^{4}$ Recent

${ }^{3}$ Borlik is here summarising a view elaborated upon by David Johnson in Shakespeare and South Africa (1996).

4 See Chris Thurman (ed.), South African Essays on 'Universal' Shakespeare (2014) and Chris Thurman, "From Shakespearean Singularity to Singular Shakespeares: Finding New Names for Will-in-the-world". Shakespeare in Southern Africa 30 (2017): 1-13. 
interventions by scholars such as Kiernan Ryan and Ewan Fernie have boldly staked a claim for an egalitarian, progressive and even revolutionary understanding of universality as expressed in and through Shakespeare's plays; South African Shakespeareans David Schalkwyk, Natasha Distiller and Laurence Wright have also offered cogent alternative approaches to Shakespearean universality. Indeed, in an age of hyper-nationalism, of the retreat into isolationism and global discord rather than globalist cooperation (the era of Trump and Putin, Brexit, the rise of the populist right wing in Europe and South America), and in which South African politicians, too, still have recourse to racial or 'ethnic' essentialism - in such a geopolitical climate, the notion of universality has increasing appeal.

Undoubtedly, the discourse of Shakespearean universality can facilitate transnational interaction. But it can also elide some of the distinct facets of that transnationalism precisely because of Shakespeare's dominance and centrality. He can develop into a totalising presence. As we have seen, this has implications for the process of translation. One problem with translators and critics presenting Dostoevsky's texts and their characters in terms of Shakespeare's plays and their characters - whether implicitly or explicitly — is that this becomes a constrained and constraining interpretive lens.

I argued in "Hamlet Underground" that, if we are to read Notes from the Underground in terms of its Shakespearean echoes, we should also be aware of Hamlet and Hamletism as a broadly European phenomenon. In Germany, of course, the ground had been prepared for Hamletomanie even before it was entrenched through the popularity of Goethe's The Sorrows of Young Werther (1774); the question of whether or not "Deutschland ist Hamlet" was, as Andreas Höfele (2016) shows, a national bone of contention throughout the nineteenth and twentieth centuries. In France, Hamletism developed very differently to the way it did in Russia: its coinage is often attributed to Mallarmé, although the prominence of Hamlet's 'image' in France dates back at least to Delacroix's famous lithographs of the 1830s and 40s, and arguably earlier (to performances of the play in Paris by Kemble, Kean and Macready that helped to redeem Shakespeare in the eyes of French neoclassicists). If Hamletism is also in Baudelaire and, later, in Laforgue, R.A. Foakes argues that it "remained a mordant presence in the consciousness of French intellectuals" (24). Foakes suggests that a line of continuity can be traced to Paul Valéry's depiction of "the figure of Hamlet brooding over millions of ghosts in the graveyard of Europe" in the wake of the First World War. Höfele writes that Valéry's Hamlet, "representing the European intellectual, is not merely unable to cope with an overwhelming task, he no longer knows what the task might be or even if there is a task at all" (Höfele 121-22).

Yet Notes from the Underground need not be connected to French literature via Shakespeare and Hamlet. On the contrary, there is a case to be 
made that the Underground Man is more directly and obviously influenced by Diderot than by anything in Shakespeare. Diderot's eighteenth-century satire Rameau's Nephew offered Dostoevsky a model both in characterisation ("The nephew parades his cynicism, flaunts his flaws, delights in making outrageous challenges to common sense and conventional wisdom, is fond of aphorisms, and manages to express many painful truths"; Lantz 95) and in style (Diderot employs an unnamed narrator, "Moi", and the nephew, "Lui", speaks in lengthy monologues). ${ }^{5}$ Kenneth Lantz notes that other "buffoons" in Dostoevsky's oeuvre that stem from Rameau's nephew include the eponymous hero of "Polzunkov" (1848) and Lebedev in The Idiot (1869).

As it happens, the French-Russian-German publishing history of Diderot's philosophical novel demonstrates how transnational literary circulation often undermines the 'national' distinctions drawn by Dostoevsky in Winter Notes on Summer Impressions - a record of his journeys to France, England, Germany, Belgium, Switzerland and Italy in 1862, published the following year in what Joseph Frank has suggested can be seen as "a first draft" of Notes from the Underground, which would appear in 1864 (Frank, "The Encounter with Europe" 237). Rameau's Nephew was composed in France between 1761 and 1774 but remained unpublished (probably because Diderot feared a repeat of the imprisonment or ban he had previously experienced) until 1805, a full two decades after the author died, when Goethe translated it into German. A copy of the manuscript had been retained in Diderot's collection of books and papers, which were protected by the patronage of Catherine the Great, and found its way from St Petersburg to Weimar via Schiller. Dostoevsky's own literary production - and subsequent reception - would likewise criss-cross the perceived or actual divide between Russia and 'the West'. Moreover, despite his insistence on the disagreeable characteristics of the British, French and German societies he encountered, this did not prevent him from enthusing over their great writers.

Indeed, Dostoevsky was enamoured of the idea of Shakespeare's universality; in his Diary of a Writer he celebrated "the world understanding and unquestionable profundity with which Shakespeare created universal human types" (in Levin, "Dostoevsky and Shakespeare" 57). Nevertheless, we cannot allow this view to guide our understanding of the relationship between the Underground Man and Hamlet. If we do, we run the risk of overdetermined readings that ignore important differences. This does a disservice to Hamletwhose author, Levin notes, "emerges as a sort of abstraction" from Dostoevsky's universalist polemics (53) - by making the dialogic (quite literally) monologic. The Shakespearean template, moreover, delimits what can be made of Notes from the Underground by English readers.

5 An alternative French precursor was casually proposed by Northrop Frye, who felt that the "dreary paranoid whine" of Rousseau's Confessions (1782) is "certainly an ancestor" of Dostoevsky's Notes (in Denham 244). 
Translators concur that Dostoevsky's stylistic experimentation in the Notes, particularly his use of colloquial language, can make translation "extraordinarily difficult" (Zinovieff and Hughes xi). As a result, translators "tend towards paraphrase rather than literal translation" and the various translations "differ from one another more widely than translations usually do" (xiii). My observations in this article, therefore, have not been made with the intention of privileging one approach to translating Dostoevsky over another. Instead, my analysis of Magarshack's 'Shakespearean' translation of Notes from the Underground has, I hope, provided an example of how readers and critics may exercise caution when it comes to the often invisible - and potentially reductive-impact of Shakespeare's universality.

Dostoevsky made universalist claims about other writers, of course, most famously in his paean to Pushkin delivered in 1880 - the year before he died, and at the culmination of that period during which he wore "the mantle of the prophet" (Frank passim). The friction between universalist and nationalist discourses is evident in Dostoevsky's address about Pushkin, which is ultimately about what he perceives as the Russian national character. Paradoxically, for Dostoevsky, it is specifically in Russia that the capacity for universal "brotherhood" may best be fostered: "Our people do bear in their souls this aptitude for responding to the entire world and for universal reconciliation ... the Russian heart is most plainly destined, among all the peoples, for universally human and brotherly unity" (Dostoevsky/Lantz 1273 and 1295). After his death Dostoevsky, too, would become canonised in universalist terms; in 'his' Russia, as in 'Shakespeare's' England, authorial universality has been used to stoke and justify nationalist excess. It is both the task and the prerogative of the translator to complicate this fusion of universalism and nationalism - translation makes possible universalist claims, but it is also a fundamentally transnational and cosmopolitan activity. For scholars of Shakespeare as well as of Dostoevsky, the transnational and translational dynamics I have sketched in this article remain keenly important.

* I am grateful to Dmitry Shkatov for his analysis of texts in Russian.

\section{WORKS CITED}

Bloom, Harold. The Anxiety of Influence: A Theory of Poetry. New York: Oxford UP, 1997.

Borlik, Todd. "Stellifying Shakespeare: Celestial Imperialism and the Advent of Universal Genius." Shakespeare in Southern Africa 26 (2014): 1-12.

Chukovsky, Kornei. The Art of Translation: Kornei Chukovsky's A High Art. Translated by Lauren G. Leighton. Knoxville: Tennessee UP, 1984. 
Denham, Robert D. A Northrop Frye Chrestomathy. Newcastle: Cambridge Scholars, 2015.

Derrida, Jacques. Of Grammatology (1967). Translated by Gayatri Chakravorty Spivak. Baltimore: Johns Hopkins UP, 2016.

Distiller, Natasha. "On Being Human" in South African Essays on 'Universal' Shakespeare, ed. Chris Thurman. Farnham: Ashgate, 2014.

Dostoevsky, Fyodor. Zapiski iz Podpol'ya (1864). Letchworth: Bradda Books, 1974.

- Winter Notes on Summer Impressions (1863). Translated by David Patterson. Evanston: Northwestern UP, 1988.

-. A Writer's Diary: Volume Two 1877-1881. Translated by Kenneth Lantz. Evanston: Northwestern UP, 1994.

- The Best Short Stories of Fyodor Dostoevsky. Translated by David Magarshack (1968). New York: Random House, 2001.

- Notes from Underground (1864). Translated by Michael Katz. New York: Norton, 2001.

- Notes from Undergound (1864). Translated by Kyril Zinovieff and Jenny Hughes. Richmond: OneWorld Classics, 2010.

Fernie, Ewan. Shakespeare for Freedom: Why the Plays Matter. Cambridge: Cambridge UP, 2017.

Foakes, R.A. Hamlet versus Lear: Cultural Politics and Shakespeare's Art. Cambridge: Cambridge UP, 1993.

Frank, Joseph. Dostoevsky: The Mantle of the Prophet, 1871-1881. Princeton: Princeton UP, 2002.

Höfele, Andreas. No Hamlets: German Shakespeare from Friedrich Nietzsche to Carl Schmitt. Oxford: Oxford UP, 2016.

Johnson, David. Shakespeare and South Africa. Oxford: Clarendon, 1996.

Lantz, Kenneth. The Dostoevsky Encyclopedia. Westport: Greenwood Press, 2004.

Levin, Yuri [Iurii]. "Dostoevsky [Dostoevskii] and Shakespeare" (1974) in Dostoevskii and Britain, ed. W.J. Leatherbarrow. Oxford: Berg, 1995.

Mochulsky, Konstantin. Dostoevsky: His Life and Work (1947). Translated by Michael A. Minihan. Princeton: Princeton UP, 1967.

Ogawa, Yasuhiro. "Hamlet and the Vision of the Grotesque" in The Grotesque in Art and Literature: Theological Reflections, ed. James Luther Adams et al. Grand Rapids: Eerdmans, 1997.

Polevoy, Nikolai. Gamlet. Moscow (Courtesy British Library), 1837.

Powys, John Cowper. Dostoievsky. London: John Lane / Bodley Head, 1946.

Remnick, David. "The Translation Wars". The New Yorker, 7 November 2005 (accessed 7 June 2018). http://www.newyorker.com/magazine/2005/11/07/the-translationwars)

Ryan, Kiernan. Shakespeare's Universality: Here's Fine Revolution. London: Bloomsbury, 2015.

Schalkwyk, David. "Foreword" in South African Essays on 'Universal' Shakespeare, ed. Chris Thurman. Farnham: Ashgate, 2014.

Thurman, Chris. "Hamlet Underground: Revisiting Shakespeare and Dostoevsky". Multicultural Shakespeare: Translation, Appropriation and Performance 18.1 (2018): 79-92. 
"From Shakespearean Singularity to Singular Shakespeares: Finding New Names for Will-in-the-world". Shakespeare in Southern Africa 30 (2017): 1-13.

Thurman, Chris (ed). 2014. South African Essays on 'Universal' Shakespeare. Burlington: Ashgate.

Wright, Laurence. “'Thinking with Shakespeare': The Merchant of Venice-Shylock, Caliban and the dynamics of social scale". Shakespeare in Southern Africa 29 (2017): 17-26. 


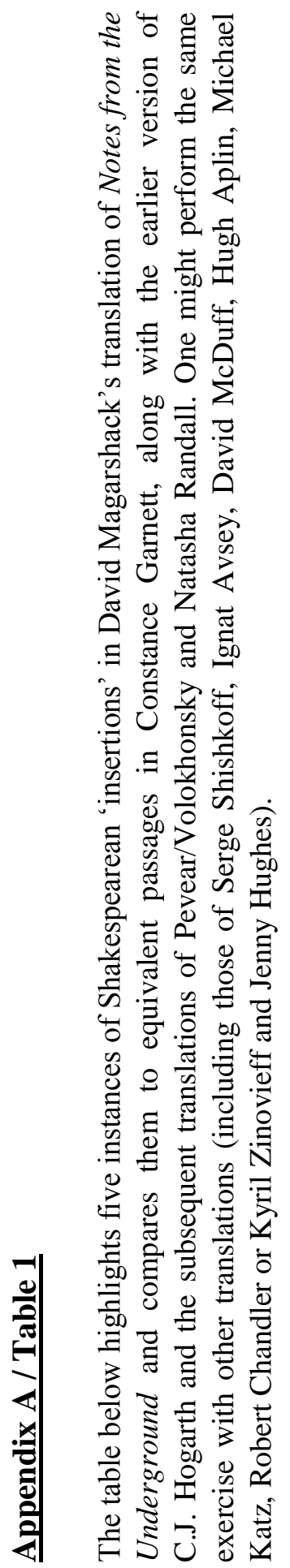

\begin{tabular}{|c|c|c|}
\hline 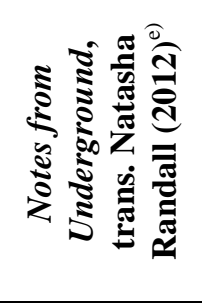 & 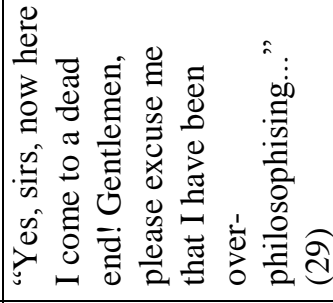 & 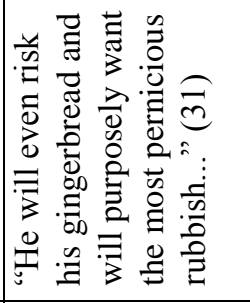 \\
\hline 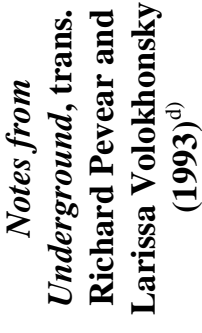 & 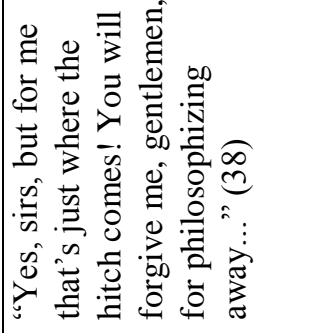 & 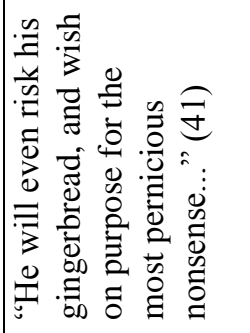 \\
\hline 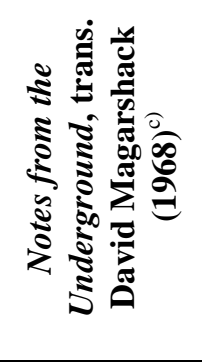 & 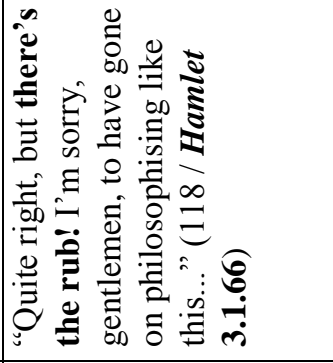 & 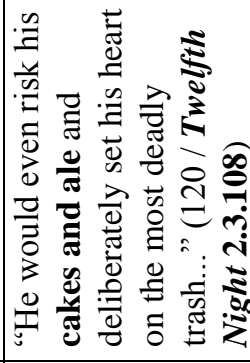 \\
\hline 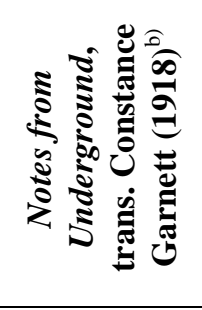 & 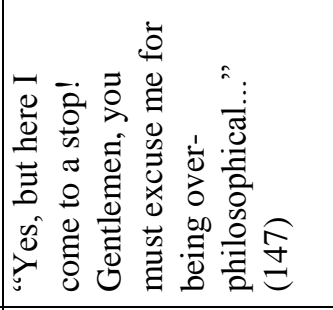 & 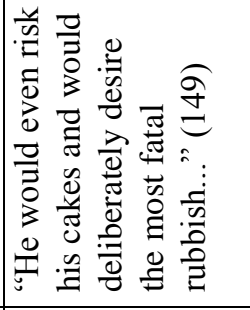 \\
\hline \multirow[t]{2}{*}{ 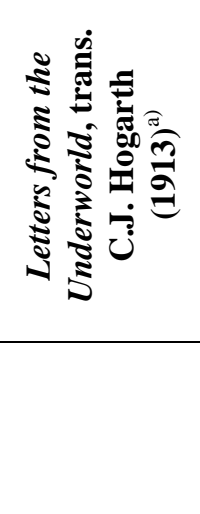 } & 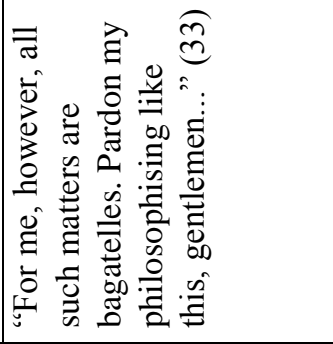 & 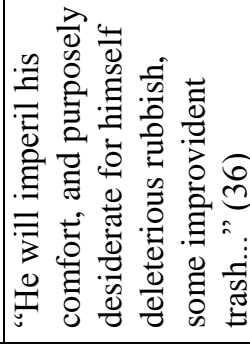 \\
\hline & 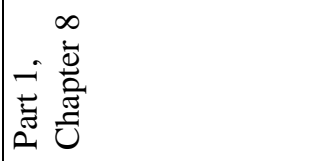 & 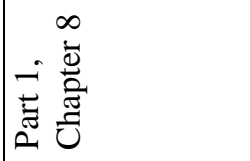 \\
\hline
\end{tabular}




\begin{tabular}{|c|c|c|c|}
\hline 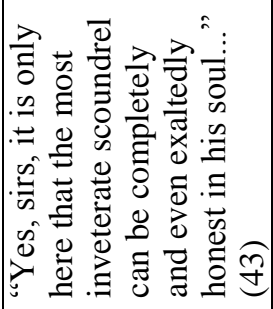 & 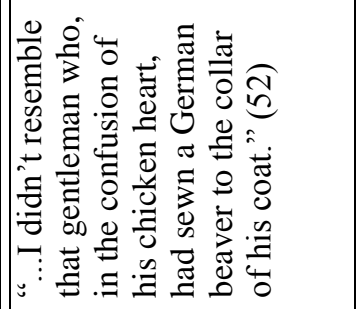 & 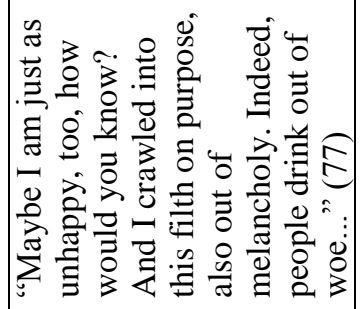 & \\
\hline 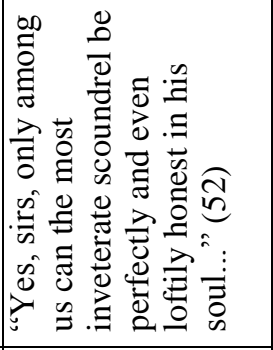 & 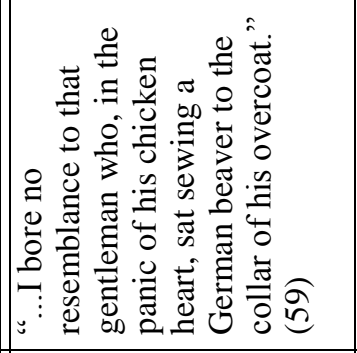 & 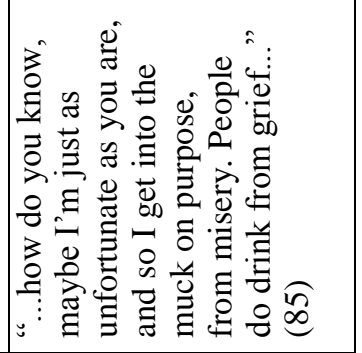 & 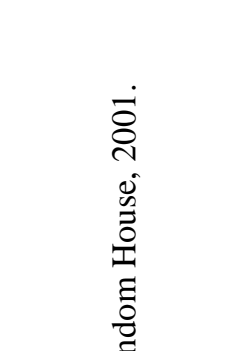 \\
\hline 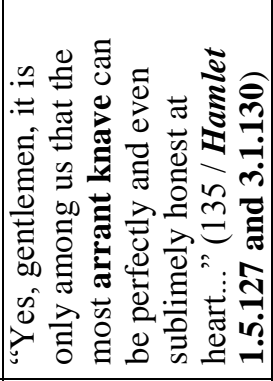 & 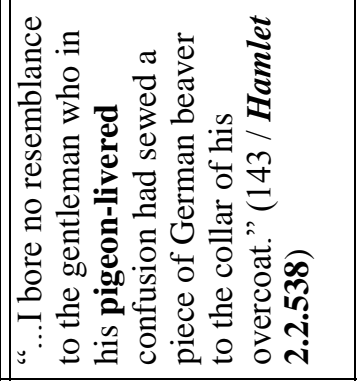 & 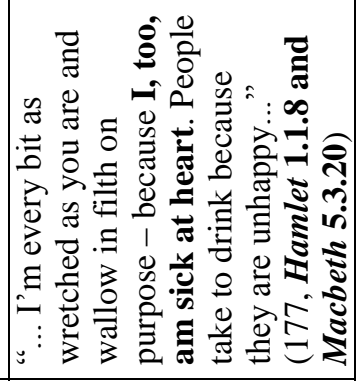 & 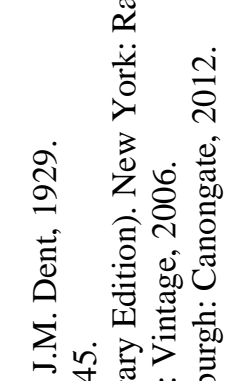 \\
\hline 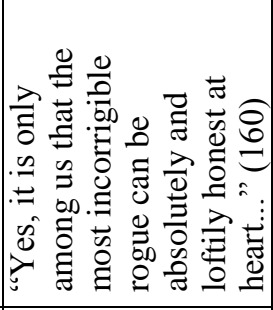 & 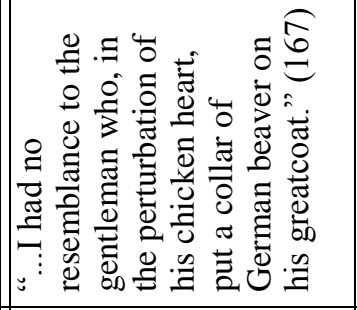 & 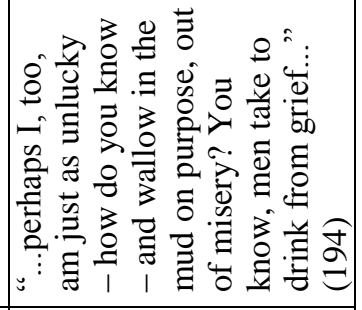 & 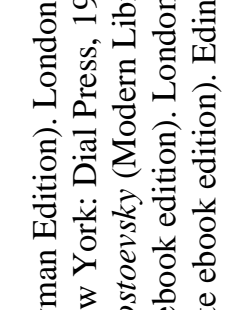 \\
\hline 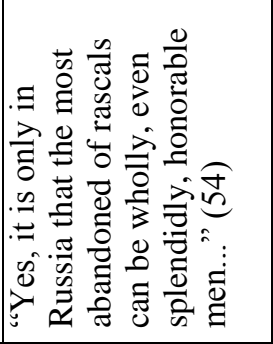 & 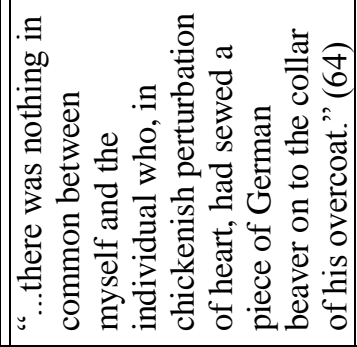 & 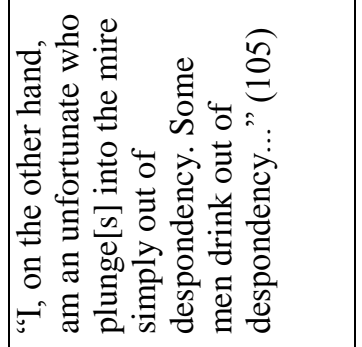 & 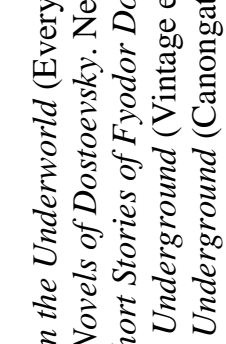 \\
\hline 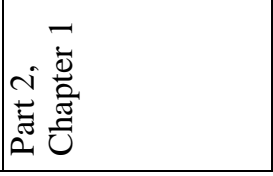 & 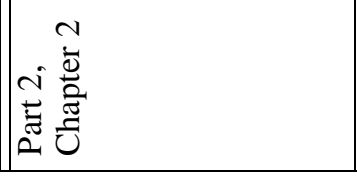 & 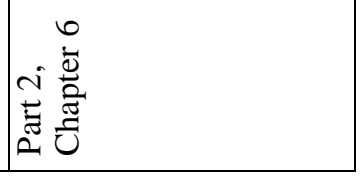 & $\hat{\sigma} \hat{0} \sigma 0$ \\
\hline
\end{tabular}

